\title{
Framkvæmd stefnu um menntun fyrir alla á Íslandi: Viðhorf skólafólks og tillögur um aðgerðir
}

\author{
Edda Óskarsdóttir, Hermína Gunnpórsdóttir, \\ Birna M. Svanbjörnsdóttir og Rúnar Sigpórsson \\ Abstract Um höfunda About the authors $>$ Heimildir
}

Menntun fyrir alla er einn af meginpáttum peirrar stefnu sem íslenskt skólakerfi er byggt á. Í úttekt Evrópumiðstöðvar um nám án aðgreiningar og sérparfir (hér eftir Evrópumiðstöðin) á framkvæmd stefnunnar, sem var birt 2017, kom fram að prátt fyrir að stefnan væri skýr hefði skólasamfélagið hvorki skýra mynd af hugtakinu menntun án aðgreiningar né fullnægjandi skilning á hvað skólastarf á peim grundvelli fæli í sér. Markmið greinarinnar er tvípætt: Í fyrsta lagi að draga saman niðurstöður 23 funda sem haldnir voru um allt land á vegum stýrihóps Mennta- og menningarmálaráðuneytisins um menntun fyrir alla haustið 2018 með pað fyrir augum að skapa umræðu um stefnuna. Til fundanna voru boðaðir fulltrúar leikskóla, grunnskóla og framhaldsskóla, frístundapjónustu, foreldrafélaga, skólaskrifstofa, félags- og skólapjónustu auk heilsugæslu. Niðurstöðurnar eru byggðar á greiningu á umræðuverkefni sem lagt var fyrir á hverjum fundi par sem pátttakendur komu sér saman um mikilvægustu breytingar sem gera pyrfti, og forgangsröðun peirra, til að styrkja menntun fyrir alla í íslenska skólakerfinu. Í öðru lagi er markmið greinarinnar að leggja fram tillögur greinarhöfunda um aðgerðir til að efla menntun fyrir alla í íslenskum skólum. Pær eru byggðar á niðurstöðum umræðuverkefnisins ásamt niðurstöðum úttektarskýrslu Evrópumiðstöðvarinnar frá 2017. Pær eru settar í samhengi við fræðilegan bakgrunn menntunar fyrir alla og enn fremur líkan af vistkerfi menntunar með pað fyrir augum að greina á hvaða stjórnsýslustigum menntakerfisins ábyrgð á framkvæmd hvers páttar liggur.

Efnisorð: Menntastefna; menntakerfi; menntun fyrir alla; skóli án aðgreiningar; lærdómssamfélag; framkvæmd stefnu

\section{Inngangur}

Á haustmánuðum 2018 boðaði stýrihópur Mennta- og menningarmálaráðuneytisins um menntun fyrir alla til funda með fulltrúum allra sveitarfélaga í landinu til að ræða um menntun fyrir alla, sem lið í mótun nýrrar menntastefnu til 2030. Með fundaröðinni var brugðist við einni af sjö megintillögum í skýrslu um úttekt á framkvæmd stefnu um menntun án aðgreiningar á Íslandi (European Agency for Special Needs and Inclusive Education, 2017, bls. 16 - hér eftir stytt í European Agency). Tillagan er að „, [t]ryggt verði að allir í skólasamfélaginu líti á skólastarf án aðgreiningar sem grundvöll gæðamenntunar fyrir alla nemendur“ og með pað fyrir augum verði efnt til umræðna „meðal peirra sem eiga hagsmuna að gæta á sviði menntamála á landsvísu og í einstökum sveitarfélögum um hvers konar skólar og lærdómssamfélög séu eftirsóknarverð og bestu leiðirnar að pví takmarki“. Segja má að pessi tillaga sé undirstaða peirra sex megintillagna sem á eftir fylgja, en pær varða aðgerðir innan allra stjórnsýslueininga menntakerfisins til að tryggja framgang stefnunnar um menntun fyrir alla. 
Pessi grein er byggð á gögnum sem safnað var á fundunum haustið 2018 og skýrslu sem skrifuð var í kjölfarið (Mennta- og menningarmálaráðuneytið, 2020). Markmið hennar er tvípætt: Í fyrsta lagi að draga saman niðurstöður úr umræðuverkefni sem pátttakendur á fundunum skiluðu og birta pannig hugmyndir peirra um nauðsynlegar breytingar til að styrkja menntun fyrir alla í íslenska skólakerfinu. Í öðru lagi að leggja fram tillögur greinarhöfunda um aðgerðir til að efla menntun fyrir alla í íslenskum skólum. Tillögurnar eru í sex liðum. Pær eru byggðar á niðurstöðum fundanna og settar í samhengi við fræðilegt efni um menntun fyrir alla og líkan af vistkerfi menntunar með pað fyrir augum að greina á hvaða stjórnsýslustigum menntakerfisins ábyrgð á framkvæmd hvers páttar liggur. Greinin er framlag til fræðilegrar umræðu um mótun menntastefnu sem byggð er á hugmyndum um félagslegt réttlæti og menntakerfi án aðgreiningar. Fyrst verður fjallað um fræðilegt samhengi stefnunnar um menntun fyrir alla, skólastarfs í anda hennar og próunar pess. Pað er síðan dregið saman í líkan af vistkerfi menntunar. Pví næst er gerð grein fyrir gögnunum sem aflað var á fundunum og úrvinnslu peirra. Pá eru niðurstöður settar fram og par á eftir tillögur greinarhöfunda. Greininni lýkur með samantekt og ályktunum.

\section{Fræðilegt samhengi}

Í pessum kafla er gerð grein fyrir pví fræðilega samhengi sem menntun fyrir alla er sprottin úr, með sérstakri áherslu á leiðir til að próa skólastarf fyrir alla.

\section{Stefna og sýn}

Segja má að inntak hugmyndarinnar um menntun fyrir alla hafi skýrst með hverri endurnýjun laga um skólastarf og aðalnámskráa síðustu tuttugu til prjátíu árin (Gretar L. Marinósson og Dóra S. Bjarnason, 2016). Núgildandi lög og aðalnámskrá taka af allan vafa um hlutverk skólans sem lýðræðislegs vettvangs samstarfs, ábyrgðar og virðingar fyrir manngildi par sem leitað er leiða til að útrýma hvers konar mismunun og aðgreiningu og koma til móts við náms- og félagslegar parfir nemenda í almennu skólastarfi. Til pess parf að líta á fjölbreytileika sem meginreglu og leitast við að ryðja úr vegi hindrunum fyrir virkri pátttöku allra nemenda í skólasamfélaginu með merkingarbærri námskrá, skilvirkri kennslu og nauðsynlegum stuðningi. Skólum er ætlað að haga námskrá, kennslu og námsumhverfi pannig að hægt sé að mennta alla nemendur á árangursríkan máta (lög um framhaldsskóla nr. 92/2008; lög um grunnskóla nr. 91/2008; lög um leikskóla nr. 90/2008; Menntaog menningarmálaráðuneytið, 2013).

Í úttektarskýrslu Evrópumiðstöðvarinnar (European Agency, 2017) er komist að peirri niðurstöðu að löggjöf og opinber stefnumörkun á sviði menntunar án aðgreiningar sé ítarleg. Hins vegar er talið að framkvæmd stefnunnar sé erfiðleikum bundin og að skólasamfélagið hafi hvorki skýra mynd af hugtakinu menntun án aðgreiningar né fullnægjandi skilning á hvað skólastarf á peim grundvelli felur í sér. Pessi niðurstaða endurómar víða í íslenskum rannsóknum par sem stjórnendur, kennarar og foreldrar telja að himinn og haf sé á milli opinberrar stefnumótunar og framkvæmdar í skólum (sjá t.d. Helga Gíslason og Önnu Kristínu Sigurðardóttur, 2016; Rannveigu Klöru Matthíasdóttur o.fl., 2013). Pessar áskoranir eru ekki einskorðaðar við íslenskt samhengi. Erlendis má sjá sambærilegar niðurstöður rannsakenda sem færa rök fyrir pví að í öllum löndum sé bil milli mótunar og framkvæmdar stefnunnar um menntun fyrir alla og að töluverðs óöryggis gæti um hvernig eigi að skapa námsrými án aðgreiningar innan skóla (Haug, 2017).

Í skýrslu Evrópumiðstöðvarinnar (European Agency, 2017) er ítrekað varað við að skortur á sameiginlegri sýn kunni að valda pví að framkvæmd við innleiðingu stefnunnar um menntun fyrir alla verði yfirborðskennd og vandamálamiðuð og að ranghugmyndir um stefnuna standi framkvæmd hennar fyrir prifum. Pví er mikilvægt að beina sjónum að markvissu námi um hvað menntun fyrir alla pýðir í raun og veru, hvers konar starfshættir eiga par við og hvers konar starfshætti parf að uppræta. 
Einn angi af óöryggi um framkvæmd stefnunnar á sér rætur í pví sem Sigrún Harðardóttir og Sigrún Júlíusdóttir (2019) fjalla um sem útvíkkað hlutverk kennara, sem feli í sér að sinna heildarlíðan nemenda í samvinnu við aðra faghópa innan og utan skólans, umfram pað sem áður var. Petta breytta hlutverk hafi valdið auknu álagi á kennara samhliða áskorunum tengdum hegðun og námserfiðleikum og pað sé krefjandi að takast á við fjölbreytileikann í nemendahópnum og mæta pörfum hvers og eins. Рað sem veldur álagi er ekki stefnan sem slík, heldur skortur á viðeigandi stuðningi og björgum til kennara sem stefnan kallar eftir. Í leikskólum eykst álagið vegna pess að skortur er á menntuðum leikskólakennurum, of mörg börn eru í rými, undirbúningstími er ónógur og starfsaðstæður eru lélegar (Kristín Dýrfjörð, 2017).

Ríkið setur menntastefnu í landinu sem sveitarfélögum er ætlað að framfylgja. Á sveitarfélögum hvílir pví rík ábyrgðarskylda og hlutverk hvað stuðning varðar. Í rannsókn Helga Gíslasonar og Önnu Kristínar Sigurðardóttur (2016) á stefnu sveitarfélaga um skóla án aðgreiningar kom hins vegar fram að sveitarfélögin sem rannsökuð voru styddust að miklu leyti við læknisfræðilegar greiningar við úthlutun fjármagns en ekki kennslufræðilegt mat á pörfum nemenda. Í pessu kjarnast togstreita milli áherslu á nemandann annars vegar og áherslu á skólapróun og breytta kennslufræði sem stefnan kallar eftir hins vegar. Höfundar draga pá ályktun að sú sýn sem birtist í stefnuskjölum sveitarfélaga um hlutverk stoðpjónustu sé enn að nokkru leyti í ósamræmi við stefnuna um skóla án aðgreiningar og að mikil pörf sé á að skýra betur hvað hún feli í sér í daglegu starfi grunnskóla.

Í nýrri rannsókn á skólapjónustu sveitarfélaga (Birna María Svanbjörnsdóttir o.fl., 2020) eru pessar ályktanir studdar enn frekar með gagnasöfnun á landsvísu. Pá má sjá sambærilega niðurstöðu í skýrslu Menntavísindastofnunar Háskóla Íslands um samantekt á lögum og fræðilegu efni um skóla án aðgreiningar (Steingerður Ólafsdóttir o.fl., 2014). Par kemur fram að ramminn um samstarf menntageirans og félags- og heilbrigðiskerfisins sé brotakenndur og óskýr og til að uppfylla ákvæði laga og alpjóðasampykkta betur en nú er gert purfi að styðja sveitarfélög og skóla til frekari sveigjanleika.

\section{Samstarf og viðhorf}

Í rannsókninni Starfshættir í grunnskólum við upphaf 21. aldar kom fram að foreldrar og starfsmenn skóla töldu samstarf sín á milli nauðsynlegt fyrir velferð og nám barna og unglinga (Kristín Jónsdóttir og Amalía Björnsdóttir, 2014). Vísbendingar eru hins vegar um að samráð skorti við foreldra um sérkennslu (Sigurður Arnar Sigurðsson, 2013) og eins gefa allmargar smærri rannsóknir og meistaraprófsverkefni til kynna að talsvert skorti á samstarf og samtal innan skóla, milli heimilis og skóla, pvert á skólastig og við ytri stofnanir. Markvisst samstarf á öllum stigum kerfisins er hins vegar mikilvægur áhrifapáttur í árangursríku skólastarfi með menntun fyrir alla í forgrunni, eins og niðurstöður Skoglund (2014) gefa til kynna í Svípjóð og Evrópu. Rannsóknir hans hafa leitt í ljós að skólar og sveitarfélög hafa próað menntun fyrir alla með pví að horfast í augu við pörfina fyrir breyttan hugsunarhátt og annars konar starfshætti, m.a. dreifðari forystu og aukna samvinnu í teymum. Jafnframt purfi að leggja áherslu á að byggja upp faglegt lærdómssamfélag og greina jákvæð áhrif eigin starfspróunar og virkrar pátttöku í samstarfi á nám nemenda.

Í Manitoba-fylki í Kanada hefur verið unnið samkvæmt líkani par sem dregin er upp heildarmynd af mismunandi stoðkerfum bæði innan og utan skóla. Pegar leitast er við að mæta fjölbreyttum pörfum nemenda er mikilvægt að tryggja að pað sé gert á heildrænan hátt með samstarfi allra peirra sem að málum koma, s.s. peirra sem starfa innan mennta-, félags- og heilbrigðiskerfis. Pá parf samvinna allra aðila að taka jafnt til allra skólastiga, p.e. leik-, grunn- og framhaldsskóla, og líta á nemanda, kennara og foreldra sem miðpunkt skólastarfsins sem nýtur góðs af skilgreindum stuðningsaðilum eða teymum, bæði innan og utan skólans (Manitoba Education and Advanced Learning, 2014).

Á síðari árum hefur fagfólki, öðrum en almennum kennurum, fjölgað í íslenskum skólum, sérkennurum par á meðal. Einnig hefur stuðningsfulltrúum fjölgað fjórfalt á 20 ára tímabili, úr 209 árið 1999 í 885 árið 2019 skv. tölum Hagstofunnar (Hagstofa Íslands, e.d.). Enn virðist 
nokkuð í land að samstarf pessara aðila sé samvirkt á pann hátt að nemandinn og parfir hans séu í brennidepli, sem og áherslur stefnunnar um skóla án aðgreiningar. Vísbendingar um petta má t.d. sjá í niðurstöðum rannsóknar Rannveigar Klöru Matthíasdóttur og fleiri (2013) en par kom fram ákveðin mótsögn sem fólst í að á sama tíma og flestir sérkennarar töldu sig hafa jákvætt viðhorf til skóla án aðgreiningar sögðust peir kenna nemendum í sérkennslustofum eða sérkennsluveri að hluta eða öllu leyti og einungis 3\% sögðust sinna sérkennslu í almennri kennslustofu. Rannveig Klara Matthíasdóttir og félagar telja niðurstöðurnar benda til pess að efla purfi samstarf bekkjarkennara og sérkennara. Pau telja enn fremur að vinnubrögðin sem lýst er í niðurstöðunum stuðli frekar að pví að rjúfa tengsl pessara tilteknu nemenda við bekkinn og bekkjarfélagana og byggi pannig upp hindranir milli nemenda sem og milli almennra kennara og sérkennara.

\section{Kennslufræði menntunar fyrir alla}

Pær kröfur sem menntun fyrir alla gerir til próunar skólastarfs hafa í för með sér að kennarar purfa stöðugt að leita að kennslufræði og aðferðum til að mæta bæði kröfum námskrár og fjölbreytni nemendahópsins (Hafdís Guðjónsdóttir og Edda Óskarsdóttir, 2020). Pær kröfur kveða skýrt á um að nám eigi að vera á forsendum hvers nemanda og lagað að „proska, persónugerð, hæfileikum, getu og áhugasviði“ (Mennta- og menningarmálaráðuneytið, 2013, bls. 42). Sömuleiðis er tekið fram í viðmiðum sem liggja til grundvallar ytra mati á grunnskólum (Menntamálastofnun, 2018) að stuðningur við einstaka nemendur fari að jafnaði fram í heimabekk nemanda samkvæmt einstaklingsnámskrá innan ramma bekkjarnámskrár.

Íslenskar rannsóknir benda pó til að kennurum veitist erfitt að laga nám að pörfum nemenda pannig að peir eigi samleið sem hópur eða bekkjarheild. Pá séu viðbrögð skóla við námserfiðleikum, til dæmis ákvörðun um sérkennslu, oft tilviljunarkennd eða byggð á læknisfræðilegum greiningum sálfræðinga (Sigrún Harðardóttir og Sigrún Júlíusdóttir, 2019). Рað leiðir til aðgreinandi sérúrræða sem eru í andstöðu við pað félagslega sjónarhorn sem einkennir stefnuna um menntun fyrir alla. Samkvæmt pví sjónarhorni eru erfiðleikar nemenda settir í samhengi við samfélagslegar hindranir sem takmarka eða útiloka pátttöku peirra, fremur en að leita skýringa í takmörkunum nemandans sjálfs (Oliver, 2013). Sigrún Harðardóttir og Sigrún Júlíusdóttir (2019) benda á að í skólakerfinu sé pörf á skýrari leiðsögn um hvernig stefnumið menntunar fyrir alla séu felld inn í áætlanir sveitarfélaga og skóla og stutt við framkvæmd peirra. Niðurstaða peirra er að lausnin felist í víðtæku samstarfi og sameiginlegri lausnaleit sérfræðinga fremur en greiningu og úrræðum sem hverfist um námsvanda einstakra nemenda. Svipaða niðurstöðu má sjá hjá erlendum fræðimönnum, til dæmis í umfjöllun Gutkin og Curtis (2009) um pað sem peir nefna skólamiðaða ráðgjöf (e. school-based consultation).

Hermína Gunnpórsdóttir og Ingólfur Ásgeir Jóhannesson (2014) benda einnig á að kennarar bregðist gjarnan við stefnunni um menntun fyrir alla með kennsluskipulagi sem kennt er við einstaklingsmiðun - og hefur pannig séð yfirbragð stefnunnar - en byggist engu að síður á aðgreiningu, par sem litið er á parfir einstaklingsins sem vandamál sem parf að laga en ekki sem viðfangsefni sem hægt er að taka á með skipulagi kennslu og starfi bekkjarins. Hugtakið einstaklingsmiðun (e. individualization/ differentiation) hefur verið áberandi í íslenskri umræðu enda pótt ekki sé alltaf skýrt hvað pað felur í sér, eins og niðurstöður Hermínu og Ingólfs bera með sér. Pað var til dæmis lykilhugtak í umfangsmikilli rannsókn á starfsháttum í grunnskólum (Gerður G. Óskarsdóttir, 2014), par sem pað var notað sem samnefnari fyrir ýmiss konar hugmyndir um nemendamiðað nám og pátttöku nemenda í ákvörðunum um pað. Í erlendum heimildum er aftur á móti víða gerður greinarmunur á einstaklingsmiðun og persónumiðun (e. personalized learning) (sjá t.d. Bray og McClaskey, 2014; European Agency, 2018). Einstaklingsmiðun felur pá í sér að kennarinn er í aðalhlutverki, gefur fyrirmæli og stýrir aðlögun til að koma til móts við námsparfir nemendahópa eða einstakra nemenda. Persónumiðun gengur aftur á móti lengra og felur í sér að nemendur stýra sínu eigin námi, bera ábyrgð á að tengja námið við áhugamál sín og taka virkan pátt í ákvörðunum um skipulag pess. 


\section{Lærdómssamfélag og menntun fyrir alla}

Áhersla á hugmyndafræði og kennslufræði menntunar fyrir alla (e. inclusive pedagogy) í námi og starfspróun kennara er undirstaða pess að vel takist til með framkvæmdina í skólum. Pessari áherslu fylgir ákall um að kennarar geti unnið með fjölbreyttum nemendahópum, séu viðbragðssnjallir og tilbúnir til samstarfs við starfsfólk skóla og aðrar fagstéttir (Hafdís Guðjónsdóttir og Edda Oskarsdóttir, 2020). Pótt mikilvægt sé að vera opinn fyrir námi án aðgreiningar og hafa jákvætt viðhorf til fjölbreytileika er pað eitt og sér ekki nóg. Einnig parf að skapa skilyrði til stuðnings fyrir nemendur og kennara og til staðar parf að vera rammi um hæfniviðmið og gæðaeftirlit. Í raun er ekki hægt að gera kennara eina ábyrga fyrir starfsháttum án aðgreiningar, heldur parf að líta á pað sem samstarfsverkefni peirra sem að skólamálum koma.

Hugtakið lærdómssamfélag er vel pekkt í íslenskri og erlendri skólamálaumræðu og gjarnan er lögð áhersla á hve mikilvægt sé að innleiða starfshætti pess til að styrkja innviði og tryggja umbætur í skólakerfinu (sjá til dæmis Fagrád um símenntun og starfspróun kennara, 2016; European Agency, 2017). Samstaða virðist vera meðal fræðimanna um að mikilvægustu einkenni pess séu: Sameiginleg ábyrgð á námi og árangri nemenda; sameiginleg sýn og gildi; starfspróun og samvirk fagmennska sem birtist meðal annars í skipulegum félagastuðningi, teymiskennslu og lausnamiðaðri samræðu; ígrundun og pekkingarsköpun. Enn fremur má nefna stjórnskipulag og forystu sem setur umbætur á oddinn og leitast við að valdefla (e. empower) kennara sem leiðtoga breytinga (e. agents of change) og skapa peim starfsumhverfi sem miðar að tengslamyndun og samvinnu (DuFour og Fullan, 2013; Hargreaves og Fullan, 2012). Markviss stuðningur og leiðsögn við kennara og aðra fagaðila á vettvangi skiptir sköpum við að innleiða, próa og viðhalda lærdómssamfélagi. Eins er mikilvægt að verkferlar, dagskipulag og innri aðstæður í skólanum styðji við samstarf (Birna María Svanbjörnsdóttir, 2015, 2019). Dví má segja að hugmyndafræði lærdómssamfélaga sé nátengd hugmyndum um fagmennsku og starfspróun, en sýnt hefur verið fram á að kennarar og stjórnendur, sem eru skuldbundnir hugmyndafræðinni, stuðla einkum að varanlegum breytingum og námi (Fullan og Hargreaves, 2016).

Ígrundun og sjálfsmat er einn af lykilpáttum pess að byggja upp lærdómssamfélag. Sjálfsmat og hagnýting pess er pó meðal pess sem talið er parfnast úrbóta í samantekt Menntamálastofnunar á niðurstöðum ytra mats á íslenskum grunnskólum árin 2013-2018. Par segir að víða purfi „að taka til hendi við að koma á góðum vinnubrögðum bæði hvað varðar framkvæmd og umbótastarf í kjölfar matsins" (Póra Björk Jónsdóttir, 2018, bls. 8). Birtingarmynd lærdómssamfélags í skólastarfi sem styður við menntun fyrir alla er eftirfarandi:

- Hefðir skólans, menning, andrúmsloft og gildi endurspegla hugmyndafræðina.

- Skólastjórnun er dreifð og leggur áherslu á að skapa lærdómssamfélag.

- Samstarfi er gert hátt undir höfð; innan skóla, við foreldra, við aðrar stofnanir og við nærumhverfið.

- Forysta skólans er með sterka sýn á menntun fyrir alla - sem pýðir að allar ákvarðanir eru teknar með stefnuna í huga.

- Allt starfsfólk skóla ber sameiginlega ábyrgð á framkvæmdinni.

- Túlkun stefnunnar má sjá í úthlutun úrræða og stuðnings, í skólastefnu, skipulagi (eins og stundatöflu), ferlum og í skólanámskrá (DuFour og Fullan, 2013).

\section{Vistkerfi menntunar fyrir alla}

Til að gera sér betur grein fyrir hvernig hægt sé að próa menntakerfi fyrir alla er hjálplegt að líta á pað sem vistkerfi sem samsett er úr ólíkum lögum eða sviðum sem bera ábyrgð á stjórnsýslu og stefnumörkun um menntun fyrir alla, starfsemi og skipulagi skóla ásamt námi og kennslu (Anderson o.fl., 2014; Florian og Black-Hawkins, 2011; Florian og Spratt, 2013). Í vistkerfinu er litið svo á að proski og nám skapist af samskiptum einstaklingsins við umhverfið og eru par helstu stoðir og ferlar 
sem hafa áhrif á pátttöku allra nemenda og parf að hafa í huga við að veita peim sem best tækifæri til náms.

Mynd 1 sýnir að nemandinn er umkringdur samtengdum kerfum sem eiga samskipti hvert við annað og mynda vistkerfið. Í ysta lagi vistkerfisins er umgjörð ríkisins (ráðuneyti), pá umgjörð sveitarfélaga, svo skólinn sem stofnun og loks námsrými nemenda. Innan hvers lags starfa hagsmunaaðilar sem hafa ákveðin hlutverk og bera ábyrgð á að móta skóla og menntakerfi sem menntar alla. Í miðju kerfisins er síðan nemandinn og hafa önnur lög pess bein og óbein áhrif á hann í leik og starfi.

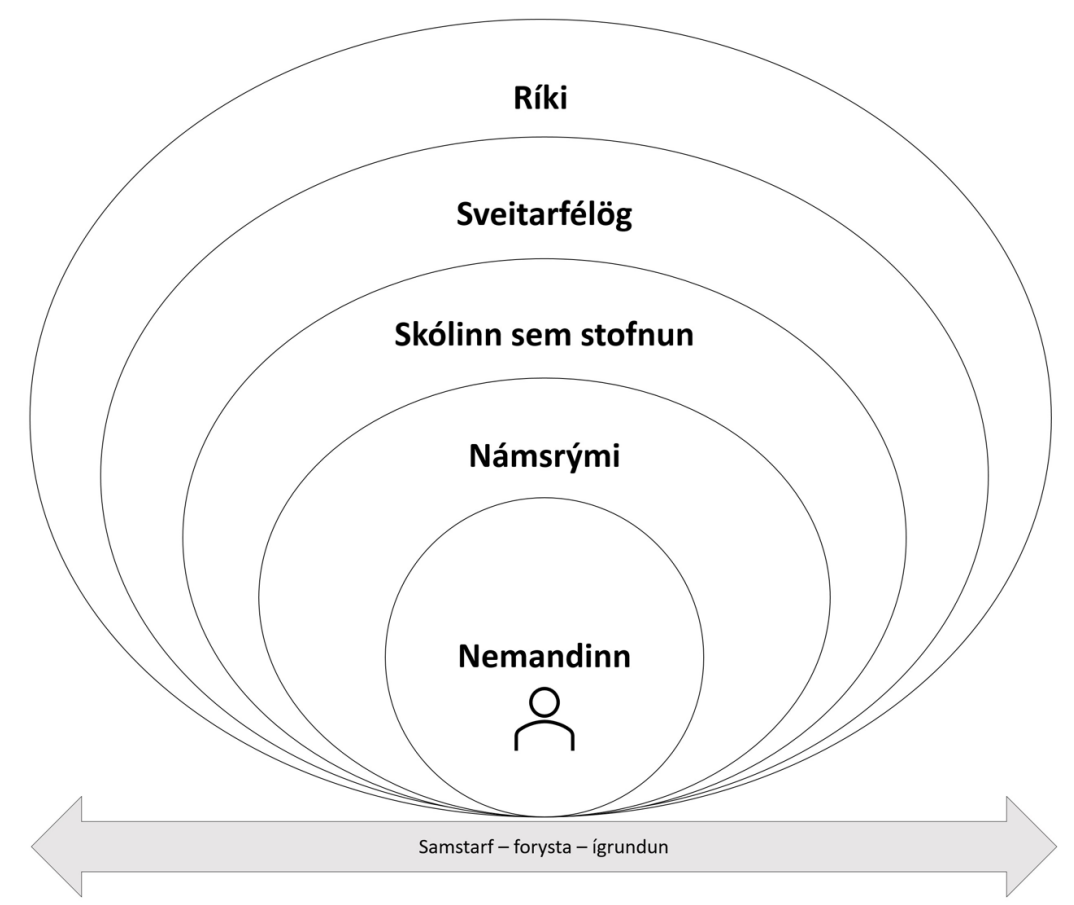

Mynd 1. Vistkerfi menntunar - fræðilegt líkan (Edda Óskarsdóttir, 2017).

Menntakerfi fyrir alla er ekki einangrað fyrirbæri. Pað er undir áhrifum menningar og samfélags, samfélagslegrar próunar og alpjóðlegra samninga og sáttmála sem Ísland er aðili að. Innan kerfisins er stöðugt streymi milli laganna par sem hvert lag er nátengt pví næsta og ekki er hægt að taka pau úr samhengi hvert við annað. Forysta, samstarf og ígrundun eru síðan mikilvægir pættir pvert á og innan hvers lags. Samskipti pvert á lögin og ákvarðanataka í hverju lagi hafa mismikil áhrif á starfsfólk og stjórnendur skóla, á nemendur og á foreldra. Ólíkir pættir í kerfinu umhverfis nemandann hafa síðan áhrif á gæði pátttöku hans, árangur og viðveru í skólanum.

Hér á eftir verður fjallað um hvert lag í vistkerfinu:

Umgjörð rikisins: Ysta lag kerfisins byggist á peim lögum og reglugerðum sem stjórnvöld setja og fylgja eftir ásamt sveitarfélögum. Samkvæmt úttekt Evrópumiðstöðvarinnar (European Agency, 2017) er stefna grunnskólalaga og aðalnámskrár í anda skóla án aðgreiningar en mikilvægt er að huga að pví að öll önnur stefnumörkun sé í anda hennar og gangi ekki pvert á pað sem ætlast er til í skólastefnunni. Pótt löggjafarvaldið og stefnumótandi aðilar séu mikilvægir í pessu lagi geta peir ekki einir og sér tryggt að menntakerfið verði án aðgreiningar. Engu að sỉur er pað hlutverk peirra að láta koma skýrt fram til hvers er ætlast af skólum án pess að gefa forskrift um leiðirnar (Pijl og Frissen, 2009). Ríkisvaldið getur aftur á móti stutt við framkvæmdina með pví að fjarlægja hindranir sem geta fundist í reglugerðum, efla starfspróun fyrir kennara og forðast fjárveitingaleiðir sem hvetja til formlegra greininga á nemendum. Hlutverk stefnumörkunar er að gefa skýra sýn á hvernig menntun fyrir alla er í framkvæmd og hvernig framkvæmdin byggir á sameiginlegri ábyrgð allra peirra sem starfa í menntakerfinu og peirra sem eru í forystu og móta stefnuna. 
Umgjörð sveitarfélaga: Í næstysta lagi kerfisins er samfélagið sem skólinn starfar í og pað skipulag sveitarfélaga sem leik- og grunnskólar starfa innan. Petta skipulag ætti einnig að styðja við pátttöku og árangur nemenda. Samhengi parf að vera milli stiga innan menntakerfisins, frá leikskóla til háskóla, og milli skóla pannig að námskrá og kennslufræði styðji nemendur í gegnum skólakerfið. Pað auðveldar tilfærslu á milli skólastiga og býr nemendur undir að takast á við fullorðinsárin. Til að mæta ólíkum pörfum allra nemenda parf stuðningur að vera aðgengilegur frá ólíkum fagaðilum (p.e. frá heilbrigðissviði, félagsmálasviði og skólapjónustu) og peir purfa að vinna saman að pví að styðja við nemendur og foreldra og við starfsemi og starfsfólk skóla (reglugerð um skólapjónustu sveitarfélaga við leik- og grunnskóla og nemendaverndarráð í grunnskólum nr. 444/2019). Sérpekking pessara aðila ætti að hjálpa starfsfólki að mæta áskorunum og auka pannig viðbragðsgetu peirra. Samfélagið ætti að skuldbinda sig til að stuðla sameiginlega að góðri menntun fyrir alla nemendur með pví að viðurkenna að menntun fyrir alla sé hluti af próun allra skóla.

Skólinn sem stofnun: Segja má að starfið í hverjum skóla stjórnist af hefðum, menningu, skólabrag, gildum og hugmyndafræði, ásamt skipulagi stjórnunar og samstarfi innan skóla, við foreldra, við ytri aðila og við nánasta samfélag skólans. Peir sem bera ábyrgð á pessu sviði eru skólastjórnendur, kennarar, starfsfólk stoðpjónustu innan skóla og almennt starfsfólk skóla. Parna ætti að sjást í skólastefnu og skólanámskrá hvernig áherslan á stefnuna um skóla án aðgreiningar kemur fram í starfinu. Skólar purfa pví í raun að skoða hjá sér hversu sýnileg stefnan er og ígrunda hvort peir starfi í raun í anda hennar. Hér skiptir stjórnun skóla máli - hvernig stjórnun er háttað, hvernig starfsfólk er ráðið, hvernig fylgst er með að starfið í skólanum sé fyrir alla og hvaða úrræði skólinn hefur upp á að bjóða til að styðja við kennara, nemendur og foreldra - hvernig aðgangur er að pessum úrræðum og hvernig pau eru nýtt.

Námsrými nemenda: Pað lag í kerfinu sem er næst nemandanum og hefur mest áhrif á hann er sú uppeldis- og kennslufræði sem byggt er á í kennslustundum. Hér er kennarinn í aðalhlutverki og mestu varðar hvernig hann skipuleggur námsrýmið, óformlegt og formlegt nám, hvernig hann skapar bekkjarmenningu og hvers konar samstarf hann á við aðra kennara og við stoðpjónustu skólans. Kennslufræði menntunar fyrir alla byggist á altækri hönnun náms og pví grundvallaratriði að hafna að hengja merkimiða á nemendur - pví pað styrkir pá ímynd að sumir nemendur hafi lítið fram að færa og getur leitt til pess að kennarar og aðrir haldi að geta sé óbreytanleg og hafi pess vegna litlar væntingar til nemenda (Gretar L. Marinósson og Kristín P. Magnúsdóttir, 2016).

Kennslufræðin krefst pess að kennarar pekki nemendur sína vel og séu viðbragðssnjallir, hugmyndaríkir, sveigjanlegir og tilbúnir að hlusta á pá. Samstarf við aðra kennara, sérkennara og stoðpjónustu er mikilvægt til að petta gangi upp. Grunngildi í kennslu sem skipta höfuðmáli til að ná markmiðum um menntun fyrir alla eru að líta á fjölbreytileika sem auðlind, veita öllum nemendum stuðning, hafa væntingar til allra nemenda, vinna með öðrum og líta á kennslustarf sem námsferli (Watkins og Donnelly, 2014). Kennarar sem byggja á pessum gildum og eru tilbúnir að vinna með fjölbreyttar parfir nemenda próa pannig kennslufræði menntunar fyrir alla.

Nemandinn: Í innsta lagi vistkerfisins eru nemendur með fjölbreytt persónuleg einkenni. Pessi einkenni ættu pó ekki að ráða hvernig nemendum vegnar í skóla, heldur ættu afdrif peirra að vera sameiginleg ábyrgð vistkerfisins í heild og tengingarnar milli laga pess. Allar ákvarðanir og athafnir í kerfinu ættu að byggjast á að ígrunda hvernig pær gagnast nemendum, pannig að peir nái árangri og tilheyri í skólanum sem fullgildir pátttakendur par sem fjölbreytileika nemendahópsins er snúið upp í tækifæri til pess að ná árangri í námi (Zubiri-Esnaola o.fl., 2020). Með árangri er vísað til afraksturs námsins í öllum páttum námskrárinnar en ekki einungis pess sem hægt er að meta með prófum eða niðurstöðum peirra.

Pátttaka nemenda og gæði peirrar reynslu sem peir öðlast í skólanum hljóta meðal annars að byggjast á að nemendur hafi eitthvað um nám sitt að segja - hafi áhrif á hvað, hvar, hvernig og með hverjum peir læra. Prátt fyrir pað virðast nemendur hafa fá tækifæri til að hafa áhrif á nám eða starf í skólum eða til að nýta hæfni sína til gagnrýni og sköpunar (Edda Óskarsdóttir, 2017). Enda pótt sums staðar megi sjá undantekningar er dagskrárvaldi kennarans sjaldan storkað (Ólafur Páll Jónsson, 2016). 


\section{Pátttakendur, gögn og úrvinnsla}

Á fundina 23 sem haldnir voru haustið 2018 voru boðaðir fulltrúar leikskóla, grunnskóla og framhaldsskóla og enn fremur fulltrúar frístundapjónustu, foreldrafélaga, skólaskrifstofa, félags- og skólapjónustu auk heilsugæslu. Rétt til pátttöku á fundunum átti 2.091 einstaklingur. Skólastjórar á öllum skólastigum voru boðaðir sérstaklega og beðnir að velja til pátttöku fulltrúa frá sínum skóla. Fundina sóttu 1.166 manns eða 56\% peirra sem boðaðir voru. Grunnskólinn átti flesta fulltrúa á fundunum, samtals 367, fulltrúar leikskóla voru 259 og frá framhaldsskólum komu 97 fulltrúar. Færri fulltrúar komu frá öðrum aðilum.

Á fundunum unnu fundargestir verkefni í sex til átta manna hópum sem bar yfirskriftina „Menntun fyrir alla: Аð ryðja hindrunum úr vegi“ og skilaði hver hópur skriflegri niðurstöðu úr umræðum sínum. Tilviljun réð samsetningu hópanna, fjöldi peirra á hverjum fundi var frá tveimur upp í tíu og alls störfuðu 126 hópar á fundunum. Markmið verkefnisins var að gefa pátttakendum færi á að íhuga pað sem peir töldu hindra menntun fyrir alla og sjá fyrir sér aðgerðir til að ryðja hindrunum úr vegi eða gera pær óskaðlegar. Um leið purftu pátttakendur að ígrunda og samræma hugmyndir sínar um hvað hugtakið menntun fyrir alla pýðir í raun og veru og hvers konar starfshættir samrýmast slíku skólastarfi. Eftir að hafa íhugað og skráð hvað helst stæði í vegi fyrir fullri virkni og pátttöku allra nemenda í skólasamfélaginu, auk hugmynda sinna um aðgerðir, purfti hver hópur að ljúka verkefninu með pví að koma sér saman um tíu mikilvægustu aðgerðirnar og raða peim í forgangsröð, í vörðu eða pýramída pannig að mikilvægasta aðgerðin kæmi efst, pá tvær í öðru sæti, prjár í priðja sæti og fjórar í neðsta lagi vörðunnar. Hver hópur fékk fartölvu til afnota og skilaði lokaniðurstöðunni á minnislykli til fundarstjóra. Fyrirmyndin að verkefninu var sótt í bókina Batt skilyrđi til náms: Starfspróun i heiltaku skólastarfi (Rósa Eggertsdóttir o.fl., 2002).

\section{Úrvinnsla}

Vörður allra hópanna voru síðan greindar með pað að markmiði að mynda sameiginlega vörðu sem endurspeglaði niðurstöður allra hópanna. Мeð pað fyrir augum voru efnisatriðin í vörðum allra hópanna kóðuð pannig að öll efnisatriðin sem hóparnir nefndu fengu kóða sem voru að lokum dregnir saman í tíu pemu til að endurspegla vörðuhugmyndina (Mynd 2).

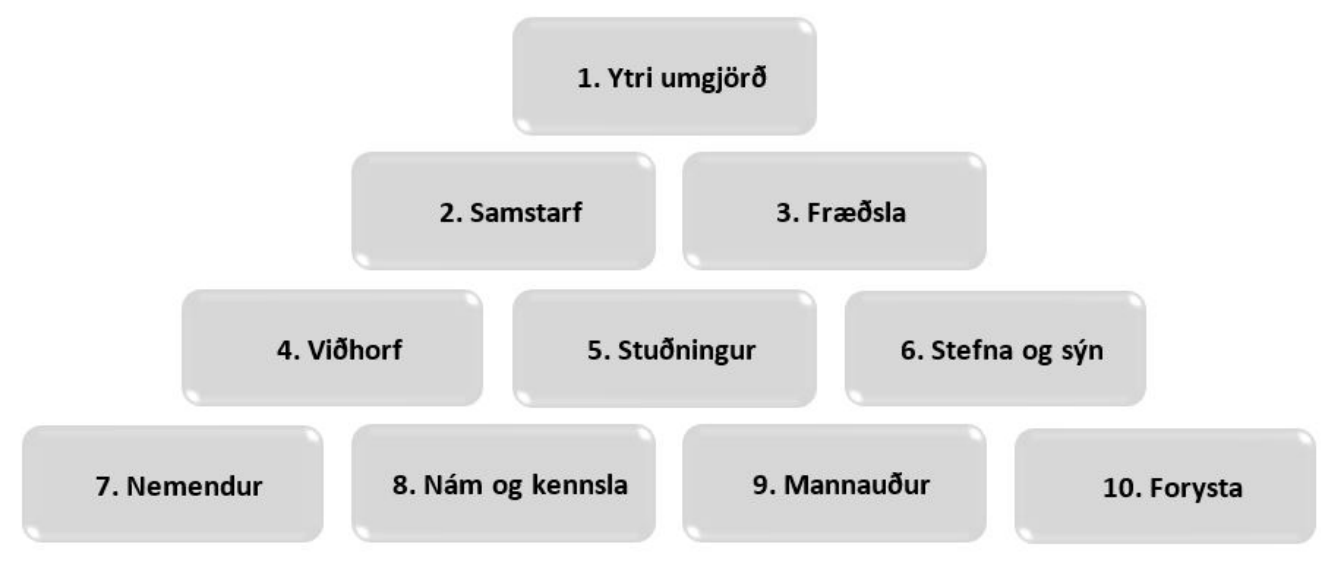

Mynd 2. Varðan - niðurstaða hópavinnu (Mennta- og menningarmálaráðuneytið, 2020).

Samtals nefndu hóparnir 1.600 efnisatriði sem voru kóðuð á pennan hátt. Pegar kóðunin lá fyrir var búin til tíðnitafla par sem efnisatriðunum var raðað eftir vægi með pví að gefa peim sem oftast voru nefnd margföldunarstuðulinn fjóra, peim sem næstoftast voru nefnd margföldunarstuðulinn prjá, peim atriðum sem voru í priðja sæti stuðulinn tvo og loks peim sem voru í fjórða sæti stuðulinn einn. Loks var samtala margfeldanna fundin og notuð til að byggja sameiginlega vörðu allra hópanna (Mynd 2). Niðurstöður greinarinnar og að hluta til tillögurnar í umræðuhluta hennar eru byggðar á pessari sameiginlegu vörðu. 


\section{Niðurstöður}

Í pessum kafla er gerð grein fyrir premur pemum sem byggð eru á vörðunni á Mynd 2. Pemun eru eftirfarandi: 1) Ytri umgjörð, samstarf og fræðsla; 2) viðhorf, stuðningur, stefna og sýn; 3) nemendur, nám og kennsla, mannauður og forysta.

\section{Ytri umgjörð, samstarf og fræðsla}

Áhersla var lögð á að endurskoða viðmiðunarreglur Jöfnunarsjóðs sveitarfélaga pannig að úthlutun fjármagns yrði óháð greiningum, p.e.a.s. að greiningar yrðu ekki forsenda fjárveitinga til skólastarfsins og skólastjórar hefðu meira vald yfir ráðstöfun fjármagns í eigin skólum. Samkvæmt tillögum hópanna parf að endurskoða vinnutíma og vinnufyrirkomulag, einkum til að auka svigrúm til undirbúnings í leikskólum, og mikilvægt er að undirbúningstími sé í samræmi við parfir nemendahópsins. Almennt parf að auka tíma og svigrúm til starfspróunar kennara, einkum í leikskólum, til að móta og innleiða breytta starfshætti og próa lærdómssamfélag. Kallað var eftir sveigjanlegri náms- og stundaskrám og fjölbreyttara innra skipulagi og lögðu hóparnir mikla áherslu á að tryggja jafnt aðgengi að pjónustu óháð búsetu og nota upplýsinga- og fjarfundatækni til að efla stoðpjónustu á landsbyggðinni. Jafnframt töldu hóparnir að bæta pyrfti upplýsingaflæði á milli allra hagsmunaaðila.

Lögð var áhersla á að efla teymiskennslu í skólum og skapa lærdómssamfélag með pví að auka samstarf kennara og efla pverfaglega samvinnu innan skólans, sem og samstarf starfsfólks og stjórnenda. Einnig komu fram sjónarmið um að efla samvinnu með foreldrum almennt en sérstaklega foreldrum barna af erlendum uppruna. Segja má að kallað hafi verið eftir samvinnu í víðum skilningi: Við aðra fagaðila (t.d. proska- og iðjupjálfa, sálfræðinga, kennslu- og uppeldisfræðinga) innan skóla, á milli skóla og frístundar, milli skólastiga, við nærsamfélagið og ekki síst milli kerfa pannig að pau „töluðu“ betur saman (s.s. skólapjónusta, félagspjónusta, barnavernd og heilbrigðispjónusta). Аð lokum var nefnt undir pessum hatti að mikilvægt væri að efla samstarf milli landshluta og á milli sveitarfélaga, m.a. um aðgengi að sérfræðibjónustu.

Hóparnir töldu pörf á að endurskoða inntak kennaramenntunar með stefnuna um menntun fyrir alla að leiðarljósi, sem og að auka pekkingu innan kennaramenntunarstofnana á viðfangsefninu og efla tengsl kennaramenntunar við vettvang skólastarfs. Menntun kennara parf að vera fjölbreyttari og styðja betur við fagmennsku peirra, meðal annars með pví að fjölga tækifærum til starfspróunar en ekki síður að auka ábyrgð starfsfólks á eigin starfspróun. Huga parf sérstaklega að starfsfólki með erlendan bakgrunn og bjóða pví upp á íslenskukennslu á starfstíma skóla. Mikilvægt er að upplýsingamiðlun á milli allra hagsmunaaðila sé skilvirk.

\section{Viðhorf, stuðningur og stefna og sýn}

Niðurstöður gáfu til kynna að breytt viðhorf væru forsenda aukinnar jákvæðni í garð stefnunnar um menntun fyrir alla hjá öllum í skólasamfélaginu, stjórnvöldum og atvinnulífinu. Bent var á að væntingar og viðhorf til nemenda pyrftu að einkennast af hugarfari vaxtar og proska. Lögð var áhersla á að markvisst pyrfti að vinna gegn rótgrónum og íhaldssömum hugmyndum og hefðum sem ynnu gegn inntaki stefnunnar, eins og í kennsluháttum og námsmati, að bóknám væri mikilvægara en annað nám og að sumir skólar (einkum framhaldsskólar) væru fyrir ákveðna nemendur en ekki aðra. Einnig var talið mikilvægt að skólastigin ynnu saman með hagsmuni nemenda að leiðarljósi.

Að mati hópanna parf skólapjónustan að vera heildstæð, fjölbreytt og samhæfð og hafa gæði náms og velferð nemenda að leiðarljósi. Einnig parf að veita pjónustuna í auknum mæli á vettvangi skólastarfs, inni í skólunum, og peir sem veita hana purfa að vera sýnilegir og aðgengilegir fyrir kennara og styðja við kennslufræðilega pætti og leiðsögn í starfi, ekki síst við nýliða. Nefnt var að samhæfa pyrfti stoðkerfin, bæði innan og utan skólapjónustunnar og auka ráðgjöf til kennara, foreldra og nemenda frá proska- og iðjupjálfum, félags- og fjölskylduráðgjöfum, sálfræðingum, uppeldisfræðingum, talmeinafræðingum og sérfræðingum hjá heilsugæslunni. Einnig pyrfti, að mati hópanna, að efla 
bjargir til að mæta betur fjölmenningarsamfélaginu með túlkabjónustu og stuðningi við kennara og foreldra barna af erlendum uppruna og virkja betur fólk af erlendum uppruna inni í skólunum. Pá var kallað eftir skólapjónustu fyrir framhaldsskólana og að unnið yrði markvisst gegn ójafnræði í skólapjónustu á grundvelli búsetu.

Pátttakendur töldu brýnt að skapa pjóðarsátt um menntastefnu til lengri tíma, tryggja skýra sýn og sameiginlegan skilning á inntaki stefnunnar Menntun fyrir alla. Skilgreina ætti mælanleg markmið fyrir hvert skólastig og ábyrgð mismunandi aðila. Kallað var eftir formlegu innleiðingarferli með aðgerðaráætlun, skýrum verkferlum og verkfærum, mati og eftirfylgni. Eins var kallað eftir sveigjanleika í nám- og stundaskrám og góðum tíma til umbreytinga. Að mati pátttakenda krefst framkvæmd stefnunnar aukins samstarf milli stofnana, skólastiga og kerfa, pað er menntakerfisins, félagslega kerfisins og heilbrigðiskerfisins, auk samfellu og upplýsingaflæðis milli skólastiga.

\section{Nemendur, nám og kennsla, mannauður og forysta}

Pátttakendur lögðu áherslu á að mæta ólíkum pörfum allra nemenda á öllum skólastigum og tryggja peim viðfangsefni við hæfi. Sérstaklega var minnst á börn af erlendum uppruna, bráđgera nemendur og börn með geðrænan vanda. Aukin fjölbreytni og sveigjanleiki í náms- og kennsluháttum, próun námsefnis og aukið val nemenda um námsgreinar og námsleiðir voru talin mikilvægir pættir í peim tilgangi. Eins töldu hóparnir mikilvægt að efla meðferðarúrræði innan skólans í samstarfi við sérfræðinga í heilbrigðis- og félagspjónustu og finna persónuverndarlögum pann farveg að pau hömluðu ekki hagsmunum nemenda. Tekið var fram að leggja pyrfti áherslu á snemmtæka íhlutun en láta greiningar eða flokkun ekki vera forsendu pess að nemendur fengju viðeigandi aðstoð og stuðning. Eins var lögð áhersla á að nemendur hefðu rödd í skólanum og meira um nám sitt að segja.

Hóparnir töldu mikilvægt að efla og próa kennsluhætti og aðra starfshætti í skólum með markvissri ígrundun í starfi, fjölbreytileika, sveigjanleika og lausnamiðun að leiðarljósi. Peir lögðu áherslu á að markmið (hæfniviðmið) væru lögð til grundvallar í kennslu en ekki námsbækur eða ákveðið námsefni, en pó pyrfti að efla námsefnisgerð sem styddi við menntun fyrir alla og nám og kennslu barna/nemenda af erlendum uppruna. Bent var á að heimila pyrfti öllum nemendum aðgang að hljóðbókum. Pátttakendur lögðu áherslu á að námskrár pyrftu að vera „lifandi“ og breytast í takt við próun samfélagsins, að sampætting námsgreina væri af hinu góða, á hverju skólastigi og innan greina pvert á skólastig, og sameina pyrfti skóla og frístund. Peir töldu bóknám vega of pungt til móts við verk- og listgreinar og að auka pyrfti sköpunarpáttinn í öllum námsgreinum ásamt áherslu á lýðheilsu og velferð nemenda. Enn fremur að námsmat pyrfti að laga að hverjum og einum í auknum mæli í stað pess að hafa sama matið fyrir alla. Í pví sambandi var talið mikilvægt að samræma skilning og útfærslu námsmatskerfisins.

Talið var mikilvægt að fjölga fagmenntuðum kennurum og sérfræðingum í skólunum og auka fjölbreytni í starfsmannahópnum, ekki síst í kennslu á leik- og grunnskólastigi, og stuðla að stöðugleika í starfsmannahaldi. Eins var talin pörf á að fjölga sérfræðingum í skólapjónustu.

Í sambandi við forystupáttinn var einkum lögð áhersla á að efla pyrfti kennslufræðilega forystu í skólum og að stjórnendur pyrftu að vera í fararbroddi með skýra sýn og skilning á inntaki stefnunnar um menntun fyrir alla. Bent var á að auka pyrfti eftirfylgd með stjórnunarháttum í skólum og styðja bæði stjórnendur og kennara í forystuhlutverkinu.

\section{Umræður}

Umræður um niðurstöður eru settar fram sem tillögur um aðgerðir til að efla menntun fyrir alla í íslenskum skólum. Pær eru jafnframt settar í samhengi við niðurstöður úttektar Evrópumiðstöðvarinnar (European Agency, 2017) og tillögur úttektarhópsins, fræðilegt efni um menntun fyrir alla, lærdómssamfélög og vistkerfi menntunar. 
Nemandinn er samnefnari allra tillagnanna og er sameiginlegt markmið aðgerðanna sem í peim felast að uppfylla markmið íslenskrar menntastefnu um menntun fyrir alla. Pessu sameiginlega markmiði fylgja síðan tillögur í sex liðum. Pær eru: 1) kennaramenntun og starfspróun, 2) lærdómssamfélög, 3) starfsaðstæður í skólum, 4) mat á skólastarfi, 5) skólapjónusta og 6) samspil kerfa og nýting fjármagns.

Kennaramenntun og starfspróun

Námsrými er pað lag sem stendur næst nemandanum í vistkerfi menntunar (Anderson o.fl., 2014) og par ráðast gæði náms og árangur pess (Mincu, 2015). Tök kennara á kennslufræði menntunar fyrir alla sem miðar að pví að auðga nám allra nemenda fremur en að búa til sérleiðir fyrir fáa nemendur eru pví lykilatriði (European Agency, 2018; Hermína Gunnpórsdóttir og Ingólfur Ásgeir Jóhannesson, 2014). Pví parf að beina sjónum að grunnmenntun kennara og líta svo á að hæfni peirra sé í stöðugri próun starfsævina á enda, með áherslu á grunngildi menntunar fyrir alla (Watkins og Donnelly, 2014). Í fundaröðinni haustið 2018 kom fram sterkt ákall um að beina athygli að menntun og starfspróun kennara og stjórnenda ásamt stuðningi við hana (Mynd 2, nr. 3 og 5). Í skýrslu Evrópumiðstöðvarinnar (European Agency, 2017) er enn fremur lögð áhersla á sömu pætti, til dæmis í 3. og 4. kafla, par sem fjallað er um stuðning við starfsfólk til að framkvæma stefnuna um menntun fyrir alla og taka mið af henni í daglegu starfi, og í 7. kafla, par sem meðal annars er fjallað um kennaramenntun og starfspróun. Enn fremur lýtur 5. tillaga úttektarhópsins (bls. 128) að pessu sama.

Í pessu ljósi gerum við tillögur um að styrkja kennslufræði menntunar fyrir alla, bæði í grunnmenntun kennara og sem grundvallarpátt í starfspróun peirra. Við göngum svo langt að leggja til að hún verði pungamiðja í starfspróunaráætlunum og starfspróun í hverjum skóla. Jafnframt leggjum við til að auk stuðnings skólapjónustu sveitarfélaga við slíka starfspróun verði hún eitt af lögboðnum hlutverkum háskólanna sem annast kennaramenntun, pannig að virk tengsl verði að pessu leyti milli háskólanna og starfsvettvangs kennara.

Ábyrgðin á að pessar tillögur komist til framkvæmda er margpætt og snertir öll lög vistkerfis menntunar. Hún liggur hjá Mennta- og menningarmálaráðuneytinu, sveitarfélögum og háskólum, og síðast en ekki síst hjá skólunum sjálfum og starfsfólki peirra.

\section{Lærdómssamfélög}

Á sîðustu árum hafa margir fræðimenn (t.d. DuFour og Fullan, 2013; Hargreaves og Fullan, 2012) notað hugtakið lærdómssamfélag sem nokkurs konar samnefnara yfir skólamenningu og margvísleg einkenni innra starfs skóla sem purfi að vera til staðar í skólum til að efla pá sem faglegar stofnanir sem geti tekist á við starfspróun og annað próunarstarf á skilvirkan hátt.

Í niðurstöðum fundaraðarinnar haustið 2018 (Mynd 2) má víða sjá kallað eftir ýmsum einkennum lærdómssamfélaga, til dæmis samstarfi og teymisvinnu (nr. 2), starfspróun og faglegu námi (nr. 3), sameiginlegri stefnu og sýn (nr. 8) og forystu (nr. 10); enn fremur að unnið sé með inntak hugmyndafræðinnar um menntun fyrir alla og kennarar aðstoðaðir við að greina starfshætti sem styðja við hana eða hamla henni.

Í skýrslu Evrópumiðstöðvarinnar (European Agency, 2017) eru umræður sem miða að mótun viðhorfa peirra sem vinna að menntun án aðgreiningar taldar meðal lyftistanga próunarstarfs í menntakerfinu. Petta endurspeglar hugmyndir um mikilvægi lærdómssamfélaga og pað gera einnig ýmsar tillögur úttektarhópsins, til dæmis 3. og 7. tillaga (bls. 115), en pær lúta meðal annars að sameiginlegri lausnaleit og formlegu sem óformlegu tengslaneti og samábyrgð fagfólks.

Í ljósi framangreindra atriða leggjum við til að próun lærdómssamfélaga verði skilgreind sem lykilpáttur í próun skólastarfs. Gerð verði áætlun um eflingu peirra í skólum landsins með 
sameiginlegu átaki undir forystu Mennta- og menningarmálaráðuneytisins með pátttöku háskóla sem annast kennaramenntun og vinna að starfspróun, sjóða sem veita styrki til próunarstarfs í skólum og skólapjónustu sveitarfélaga í samstarfi við háskólastofnanir.

Ofangreindar tillögur kalla á frumkvæði frá stjórnvöldum, Mennta- og menningarmálaráðuneytinu og sveitarfélögum en ábyrgðin hvílir ekki síður á skólum og kennurum sjálfum pví peir, ásamt öðrum í skólanum, mynda pað lærdómssamfélag sem hér er kallað eftir.

\section{Starfsaðstæður í skólum}

Skólar á Íslandi eru að jafnaði vel búnir hvað varðar húsakost, starfsumhverfi og búnað. Pað er einnig ein af niðurstöðum skýrslu Evrópumiðstöðvarinnar (European Agency, 2017) að pað megi „með góðum rökum halda pví fram að íslenska menntakerfið búi við tiltölulega góða fjármögnun“ (bls. 91) enda pótt ráđstöfun fjármagns sé gagnrýnd í skýrslunni. Pó er ekki allt sem sýnist. Svör pátttakenda í rannsókn Kristínar Dýrfjörð (2017) á álagspáttum í starfi leikskóla bera með sér að kennarar búi við verulegan aðstöðumun eftir skólastigum hvað framangreinda pætti varðar og par standi leikskólinn höllum fæti. Í niðurstöðum fundaraðarinnar 2018 kom fram sterkt ákall um breytingar á pví.

Jafnframt berast fréttir, m.a. frá samtökum kennara, um vaxandi álag í starfi og hærri tíðni kulnunar meðal leik- og grunnskólakennara (sjá t.d. Axel Helga Ívarsson, 2018; Báru Huld Beck, 2017; Guðríði Arnardóttir, 2017; Samstarfsnefnd Sambands íslenskra sveitarfélaga og Félags grunnskólakennara, 2017; Sigrúnu Daníelsdóttur, 2017). Flest í framangreindum gögnum bendir til að petta álag tengist einkum starfsumhverfi kennara, svo sem skorti á stuðningi á vettvangi, meðal annars við að mæta fjölbreyttum pörfum nemenda og innleiða nýjar námskrár, skorti á teymisvinnu og félagastuðningi og óánægju með aðbúnað, tæki og gögn.

Í ljósi framangreindrar greiningar, og með pað fyrir augum að hafa jákvæð áhrif á margt af pví sem veldur álagi í starfsumhverfi kennara, leggjum við til að gerðar verði breytingar á starfsumhverfi leikskólakennara sem tryggi peim aukinn tíma til að sinna undirbúningi og starfspróun á vinnutíma og jafnframt verði gert átak til að fjölga menntuðum leikskólakennurum. Einnig er brýnt að rannsaka hvað veldur vaxandi álagi og kulnun meðal kennara og ráðast í breytingar á starfsumhverfi peirra á grundvelli niðurstaðna slíkrar rannsóknar.

Pessar tillögur kalla fyrst og fremst á ábyrgð og frumkvæði sveitarfélaga, að pví er varðar leik- og grunnskóla, og ríkisins sem rekur framhaldsskóla. Jafnframt má færa rök fyrir pví að starfsumhverfi kennara sé að nokkru leyti háð stofnanamenningu og innri aðstæðum í skólum og sé par meðá ábyrgð skólastjórnenda.

\section{Mat á skólastarfi}

Mat á skólastarfi er nátengt hugmyndum um lærdómssamfélög en hefur einnig skírskotun til menntakerfisins í heild, enda er bæði innra og ytra mat lögbundið viðfangsefni á öllum skólastigum. Samkvæmt leik- og grunnskólalögum ber sveitarfélögum að fylgja eftir að slíkt mat leiði til umbóta í skólastarfi (lög um grunnskóla nr. 91/2008; lög um leikskóla nr. 90/2008) og ber Mennta- og menningarmálaráðuneytinu að fylgja eftir ytra mati í framhaldsskólum (lög um framhaldsskóla nr. 92/2008). Ytra mat á skólum er unnið af Menntamálastofnun og Reykjavíkurborg en fátt er vitað um hvernig ríki og sveitarfélög bregðast við niðurstöðum pess og uppfylla lagaskyldu sína um að matið leiði til umbóta. Eitt af pví sem metið er í ytra matinu er pað hvernig grunnskólar skipuleggja innra mat sitt (eða sjálfsmat sitt). Í samantekt Menntamálastofnunar (Póra Björk Jónsdóttir, 2918) kemur fram að mikilla úrbóta sé pörf varðandi skipulag pess og framkvæmd og hagnýtingu til umbóta.

Mat sem ekki leiðir til aðgerða er í raun og veru fánýt iðja og pess vegna leggjum við til að gert verði átak til að efla sjálfsmat skóla á öllum skólastigum og tryggja skólum stuðning við framkvæmd pess og úrvinnslu, ekki síst umbótaáætlanir í kjölfar bæði sjálfsmats og ytra mats. Enn fremur að sett verði 
viðmið um gæði skólastarfs sem taka mið af menntun fyrir alla og eflingu peirra innviða skólastarfs sem fjallað er um í pessum tillögum.

Ábyrgð á framkvæmd pessara tillagna hvílir að miklu leyti á Mennta- og menningarmálaráðuneytinu og Menntamálastofnun, sem og sveitarfélögum og skólum. Próun viðmiða um gæði skólastarfs parf að vera í nánu samstarfi milli pessara aðila, með pátttöku stéttarfélaga kennara og skólastjóra, og matsfræðinga á vegum háskóla. Ábyrgð á stuðningi við skóla ætti að liggja hjá skólapjónustu á vegum peirra sem reka skóla á hverju skólastigi; ríkis vegna framhaldsskóla og sveitarfélaga vegna leik- og grunnskóla.

\section{Skólapjónusta}

Í pessum tillögum er gengið út frá pví að skólapjónusta sveitarfélaga gegni veigamiklu hlutverki í próun skólastarfs og að hlutverk hennar felist meðal annars í ráðgjöf við kennara og pátttöku í starfspróun og öðru próunarstarfi, mati á skólastarfi ásamt samhæfingu sérfræðinga innan skóla sem utan er koma að málefnum nemenda sem purfa stuðning í skóla (reglugerð um skólapjónustu sveitarfélaga við leik- og grunnskóla og nemendaverndarráð í grunnskólum nr. 444/2019). Í tillögunum er lögð áhersla á að efla alla pessa pætti í starfi skólapjónustu og að stuðningur hennar við nemendur og foreldra einkennist af félagslegu sjónarhorni á einstaklingsparfir nemenda og skólamiðaðri ráðgööf (e. school-based consultation) (Gutkin og Curtis, 2009). Hún byggist á sameiginlegri lausnaleit sérfræðinga, kennara og foreldra par sem samspil nemenda og parfa peirra og námsumhverfis er í forgrunni. Lögð er áhersla á að laga kennslu, nám og námsumhverfi að pörfum nemenda. Enda pótt utanaðkomandi sérfræðingar taki pátt í skólamiðaðri ráðgjöf ber starfsfólk skóla eftir sem áđur ábyrgð á aðgerðunum sem af henni leiða; pað lærir af ráðgjöfinni og hún verður pannig hluti af starfspróun pess. Rannsóknir (Birna María Svanbjörnsdóttir o.fl., 2020; Sigrún Harðardóttir og Sigrún Júlíusdóttir, 2019) benda til að viðbrögð skóla við erfiðleikum nemenda og skólapjónusta séu mjög lituð af klínísku og sérkennslumiðuðu sjónarhorni á „vanda“ nemenda, sem er í raun andstæða hins félagslega (Oliver, 2013). Skólapjónusta er auk pess mjög misjöfn eftir sveitarfélögum (Birna María Svanbjörnsdóttir o.fl., 2020) og nær hvorki til framhaldsskóla né tónlistarskóla.

Margar af tillögunum í niðurstöðum fundanna 2018 (Mynd 2) lúta á einn eða annan hátt að skólapjónustu, svo sem óskir um fræðslu og starfspróun (nr. 3), faglegan stuðning og ráðgjöf á vettvangi (nr. 5) og stuðning við breytta kennsluhætti (nr. 8). Efling skólapjónustu, samstarf hennar við háskólastofnanir og stuðningur hennar við starfsfólk til að taka mið af menntun fyrir alla í daglegu starfi, er einnig nefnd í niðurstöðum úttektar Evrópumiðstöðvarinnar (European Agency, 2017) sem eitt af brýnustu úrlausnarefnunum (bls. 79-85, 122).

Til pess að efla stuðning við skóla og starfsfólk peirra leggjum við til að sett verði á fót heildstæð skólapjónusta sem nær til leikskóla, grunnskóla, tónlistarskóla og framhaldsskóla, reglugerð um pjónustuna verði endurskoðuð, sett verði viðmið um starfshætti hennar og Menntamálastofnun falið að annast ytra mat á pjónustunni á grundvelli peirra. Pá er brýnt að komið verði á virkara og víðtækara samstarfi milli háskóla og skólapjónustu, meðal annars um starfspróun og rannsóknir á skólastarfi, og loks parf að leita leiða til að fámenn sveitarfélög geti veitt pá pjónustu sem peim ber samkvæmt grunnskólalögum og reglugerð um skólapjónustu, annaðhvort með pjónustusamningum við önnur sveitarfélög eða stofnun byggðasamlaga. Enn fremur verði með breyttum viðmiðum og vinnureglum við úthlutun og nýtingu fjármagns vegna einstakra nemenda dregið úr vægi klínískrar nálgunar að viðfangsefnum pjónustunnar en lögð áhersla á stuðning við starf kennara og skóla og samhæfingu annarra sérfræðinga sem starfa í námsrými nemenda.

Ábyrgð á framangreindum tillögum liggur bæði hjá ríki og sveitarfélögum; ábyrgð á skólabjónustu við leik- og grunnskóla liggur hjá sveitarfélögum en ábyrgð á skólapjónustu við framhaldsskóla hjá ríkinu sem rekstraraðila peirra. 


\section{Samspil kerfa}

Í skýrslunni um úttekt Evrópumiðstöðvarinnar (European Agency, 2017) er komist að peirri niðurstöðu að sú klíníska áhersla á pjónustu við börn sem lýst er hér að framan leiði til ofuráherslu á greiningar á ýmsum flokkum einstaklingsparfa, sem síðan séu notaðar til að réttlæta fjárveitingar frá Jöfnunarsjóði sveitarfélaga og sveitarfélögunum sjálfum vegna pessara nemenda. Í skýrslunni draga höfundar pá ályktun að petta fyrirkomulag vinni gegn menntun fyrir alla, par sem pað beini fjármagni að einhvers konar sérúrræðum fyrir afmarkaðan hóp nemenda í stað pess að nýta pað í págu allra og byggja upp heildrænt skipulag til að mæta fjölbreyttum pörfum nemenda. Í slíku skipulagi parf starfsfólk skóla, svo sem almennir kennarar og stjórnendur, sérkennarar, iðjupjálfar og proskapjálfar, að vinna saman að stuðningi við nemendur. Pað krefst pess einnig að pjónustukerfi utan skólans, svo sem skólapjónusta, félagspjónusta, barnavernd og heilbrigðiskerfi, sé samhæft í hliðstæðum tilgangi (sjá til dæmis Manitoba Education and Advanced Learning, 2014; Sigrúnu Harðardóttur og Sigrúnu Júlíusdóttur, 2019; Skoglund, 2014). Í fundaröðinni kom fram sterkt ákall um samstarf af pessu tagi sem tengdist ytri umgjörð, breyttum viðmiðum um nýtingu fjármagns, samstarfi, mannauði og stuðningi við nemendur (Mynd 2).

Til að brjótast út úr pessum vítahring leggjum við til að haldið verði áfram starfi sem pegar er hafið við endurskoðun á reglum sem nú gilda um aðgang skóla að fjármunum pannig að peim sé ráðstafað í págu menntunar fyrir alla og til að efla samhæfingu mannauðs og pjónustukerfa. Á petta er lögð áhersla í einni af lyftistöngunum sem fjallað er um í skýrslu Evrópumiðstöðvarinnar (European Agency, 2017, bls. 137-141). Enn fremur að skólar fái stuðning við próunarstarf og innleiðingu lærdómssamfélaga og kennslumiðaða ráðgjöf við úrlausn einstaklingsmála (Gutkin og Curtis, 2009) til að samhæfa vinnu sérfræðinga innan skólans. Jafnframt verði unnið skipulega að samhæfingu skólapjónustu, félagspjónustu og heilbrigðispjónustu með pað fyrir augum að mæta pörfum barna og foreldra á heildrænan hátt.

Hér er um að ræða mjög viðamikið viðfangsefni, gengur ábyrgð á pví í gegnum öll lög vistkerfisins og kallar á víðtæka samábyrgð og sameiginlegar ákvarðanir ráðuneyta, sveitarfélaga og stofnana á peirra vegum.

\section{Samantekt og ályktanir - hvað svo?}

Íslensk skólastefna setur metnaðarfull markmið um menntun fyrir alla. Samkvæmt niðurstöðum úttektar Evrópumiðstöðvarinnar (European Agency, 2017) er pó ýmislegt óunnið við að koma stefnunni í framkvæmd. Með fundunum sem haldnir voru um allt land haustið 2018 var skapaður vettvangur til að hlusta á raddir skólasamfélagsins, stjórnsýslu menntakerfisins og peirra stofnana sem styðja skóla í að framfylgja stefnunni og samræma viðhorf pessara aðila pannig að peir tali einum rómi um menntun fyrir alla. Greining á niðurstöðum fundanna og pær tillögur sem hér fylgja geta verið leiðarvísir til að stuðla að áframhaldandi próun menntakerfisins.

Ljóst er pó að pessum tillögum verður ekki hrint í framkvæmd nema með víðtæku samráði og sameiginlegum ákvörðunum peirra sem eru í forsvari fyrir öll lög vistkerfisins. Eðlilegt er að líta svo á að Mennta- og menningarmálaráðuneytinu beri að taka forystu í pví verkefni og leita eftir samvinnu við sveitarfélögin, viðeigandi ráðuneyti, kennaramenntunarstofnanir og kennarafélög til að tryggja tillögunum brautargengi. 


\section{Implementing the policy of inclusion in Iceland: Teachers' views and proposals for action}

Inclusive education is a prominent feature of Icelandic educational policy. However, an external audit by the European Agency for Special Needs and Inclusive Education (2017) revealed that even though the policy is clear, administrators and practitioners within the school system lack clarity about the concept of inclusion and a deeper understanding of what constitutes inclusive practices in schools.

One of seven main recommendations of the audit is to "Ensure that all stakeholders understand inclusive education as the basis for high-quality education for all learners", and, to that end, organise "national and local-level dialogue about the kind of schools and learning communities that stakeholders want and the best ways to achieve/develop those" (p. 16). To respond to this recommendation, 23 meetings were held across Iceland to discuss the advancement of education for all, organised by a task force assigned by the Ministry of Education and Culture. Representatives of preschools, primary and secondary schools, leisure services, parents, municipal school services, social services and health care from all Icelandic municipalities were invited to the meetings. At the meetings, participants worked on projects in groups of six to eight. Each group was asked to agree on the ten most important actions to promote education for all and to prioritize them as a pyramid so that the most important action would come first, then two in second place, three in third, and so on. Each group's pyramid was then analysed in order to form a single pyramid reflecting the common conclusion of the groups.

The aim of this paper is twofold: The first aim is to present the findings from the 23 meetings based on the analysis described above. The conclusions contain three themes: 1) External framework, cooperation and education; 2) attitudes, support, policy and vision; 3) students, learning, and teaching. The first theme focused on reviewing the guidelines of the Municipalities Equalization Fund so that the allocation of funds would be independent of diagnoses and in order to increase the time and scope for professional development of teachers, especially in preschools. There were calls for more flexible curricula and timetables and for a more diverse internal organization, as well as ensuring equal access to services regardless of residence, strengthening team teaching in schools and creating a learning community by increasing teacher collaboration and interdisciplinary collaboration within the school, as well as cooperation between staff and management. In the second theme, it was thought that changing the attitudes of everyone in the school community was a prerequisite for increased positivity towards education for all, that expectations and attitudes towards students needed to be characterized by a mindset of growth and development, that school services needed to be holistic and diverse, and that the work of those who provide them needed to be better coordinated. Furthermore, there were calls for a formal process to implement the policy of education for all through an action plan, clear procedures, evaluation, and a follow-up. In the third theme, participants focused on meeting the different needs of all students in school and ensuring that they received suitable assignments; special mention was made of children of foreign origin, precocious students and children with mental health problems. The groups considered it important to develop practices in schools with purposeful reflection at work, diversity, flexibility, and the search for solutions. They considered it important to increase the number of professional teachers and other experts in the schools, to strengthen the pedagogical leadership of education for all, with managers at the forefront, and to support both managers and teachers in their leadership roles.

Secondly, the paper aims to present the authors' proposals for promoting education for all in Iceland. The proposals are based on the aforementioned findings from the meetings and underpinned by the results of the external audit of the European Agency (2017) and 
the knowledge base of inclusion and professional learning communities to create the conditions for improving practice. Furthermore, an ecosystem model of the education system is employed to identify the responsibility of each level and establish a vision of shared responsibility across the levels. The student is the common denominator in all the proposals, whose common goal is to fulfil the objectives of the Icelandic education policy on education for all. This common goal is followed by proposals in six sections: 1) teacher education and career development, 2) learning communities, 3) working conditions in schools, 4) evaluation of schoolwork, 5) school services and 6) the interplay of systems and the utilization of resources.

Keywords: Educational policy; education system; inclusive education; policy implementation; professional learning community

\section{Um höfunda}

Edda Óskarsdóttir (eddao@hi.is) er lektor við Menntavísindasvið Háskóla Íslands. Hún lauk meistaraprófi í sérkennslu frá Háskólanum í Oregon í Bandaríkjunum 1993 og doktorsprófi frá Háskóla Íslands 2017. Rannsóknarsvið hennar er einkum skóli án aðgreiningar og í tengslum við pað kennaramenntun, starfspróun kennara ásamt stefnumótun og próun skólastarfs sem stuðlar að menntun fyrir alla.

Hermína Gunnpórsdóttir (hermina@unak.is) er prófessor við kennaradeild Háskólans á Akureyri og Menntavísindasvið Háskóla Íslands. Hún hefur starfað við leik-, grunnog framhaldsskóla og lauk doktorsprófi frá Háskóla Íslands 2014. Helstu viðfangsefni hennar í kennslu og rannsóknum tengjast félagslegu réttlæti í menntun, skóla og námi án aðgreiningar, fjölmenningu og menntun, fötlunarfræði, menntastefnu og framkvæmd.

Birna María Svanbjörnsdóttir (birnas@unak.is) er dósent við kennaradeild Háskólans á Akureyri. Hún lauk B.Ed.-prófi frá Kennaraháskóla Íslands 1988 og starfaði sem grunnskólakennari um árabil. Hún lauk M.Ed.-gráðu frá Háskólanum á Akureyri 2005 og doktorsprófi í menntunarfræðum frá Háskóla Íslands 2015. Helstu áherslur í rannsóknum hennar lúta að starfspróun kennara, starfstengdri leiðsögn og uppbyggingu og próun faglegs lærdómssamfélags.

Rúnar Sigpórsson (runar@unak.is) er prófessor emeritus við kennaradeild Háskólans á Akureyri. Hann lauk meistaraprófi í skólapróun frá Háskólanum í Cambridge í Englandi 1996 og doktorsprófi í menntunarfræði frá Kennaraháskóla Íslands 2008. Rannsóknarsvið hans er einkum námskrá, kennslutilhögun, nám og námsmat, ásamt stefnumótun og próun skólastarfs á pessum sviðum.

\section{About the authors}

Edda Óskarsdóttir (eddao@hi.is) is an assistant professor at the School of Education, University of Iceland. She graduated with an MA in special needs education from the University of Oregon, USA, in 1993 and holds an EdD in Education from the University of Iceland. Her research focus is mainly on inclusive education in connection with teacher education, teachers' professional learning and development, school development and policy making.

Hermína Gunnpórsdóttir (hermina@unak.is) is a professor at the University of Akureyri and the University of Iceland. She holds a PhD from the University of Iceland (2014). She has worked at kindergarten, primary and secondary schools. Her teaching and research interests relate to social justice in education, inclusive school and education, multiculturalism and education, disability studies, educational policy and practice. 
Birna María Svanbjörnsdóttir (birnas@unak.is) is an associate professor at the University of Akureyri. She graduated with a B.Ed. in 1988 and has a long teaching career. Birna completed a master's degree from the University of Akureyri in 2005 and a Ph.D. in educational sciences from the University of Iceland 2015. Her main emphases in research are teacher development, mentoring and professional learning communities.

Rúnar Sigpórsson (runar@unak.is) is professor emeritus at the University of Akureyri. He finished an MPhil in school development from the University of Cambridge in 1996 and holds a $\mathrm{PhD}$ in education from the Iceland University of Education. His recent research relates to curriculum, classroom practice, student learning and assessment, along with educational policy and improved practice in those fields.

\section{Heimildir}

Anderson, J., Boyle, C. og Deppeler, J. (2014). The ecology of inclusive education: Reconceptualising Bronfenbrenner. Í H. Zhang, P. W. K. Chan og C. Boyle (ritstjórar), Equality in education: Fairness and inclusion (bls. 23-34). Sense Publishers.

Axel Helgi Ívarsson. (2018). Kulnun í starfi er vaxandi vandamál hjá kennurum. Mbl.is. https://www.mbl.is/ frettir/innlent/2018/08/27/kulnun_i_starfi_vaxandi_vandamal/

Bára Huld Beck. (2017). Lág laun og álag flæmir kennara burt úr skólum. Kjarninn. https://kjarninn.is/skyring/2017-12-14-lag-laun-og-alag-flaemir-kennara-burt-ur-skolum/

Birna María Svanbjörnsdóttir. (2015). Leadership and teamwork in a new school: Developing a professional learning community [doktorsritgerð, Háskóli Îslands]. Skemman. http://hdl.handle.net/1946/20818

Birna María Svanbjörnsdóttir. (2019). Teymisvinna og forysta: Birtingarmynd fimm árum eftir að innleiðingarferli faglegs lærdómssamfélags lauk. Netla - Veftimarit um uppeldi og menntun. https://doi.org/10.24270/ netla.2019.3

Birna María Svanbjörnsdóttir, Hermína Gunnpórsdóttir, Jórunn Elídóttir, Rúnar Sigpórsson og Sigríður Margrét Sigurðardóttir. (2020). Skólapjónusta sveitarfélaga við leik-og grunnskóla: Niðurstöður spurningakönnunar til leikskólastjóra, grunnskólastjóra og forsvarsaðila skólapjónustu. https://www.unak.is/static/files/pdf-skjol/2020/ skyrsla_loka_m.forsidu_28.02.20.pdf

Bray, B. og McClaskey, K. (2014). Make learning personal: The what, who, WOW, where, and why. Corwin Press.

DuFour, R. og Fullan, M. (2013). Cultures built to last: Systemic PLCs at work. Solution Trees Press.

Edda Óskarsdóttir. (2017). Constructing support as inclusive practice: A self-study [doktorsritgerð, Háskóli Íslands]. Opin visindi. https://opinvisindi.is/handle/20.500.11815/388

European Agency for Special Needs and Inclusive Education. (2017). Menntun fyrir alla á Íslandi: Úttekt á framkvamd stefnu um menntun án aðgreiningar á Íslandi. https://www.stjornarradid.is/lisalib/getfile.aspx?itemid=cca962f5-be4f-11e7-9420-005056bc530c

European Agency for Special Needs and Inclusive Education. (2018). Key actions for raising achievement: Guidance for teachers and leaders. https://www.european-agency.org/sites/default/files/Key\%20Actions\%20 for\%20Raising\%20Achievement.pdf

Fagráð um símenntun og starfspróun kennara. (2016). Skýrsla til mennta- og menningarmálaráðherra. http:// starfsthrounkennara.is/wp-content/uploads/2019/03/skyrsla160310.pdf

Florian, L. og Black-Hawkins, K. (2011). Exploring inclusive pedagogy. British Educational Research Journal, 37(5), 813-828. https://doi. org/10.1080/01411926.2010.501096

Florian, L. og Spratt, J. (2013). Enacting inclusion: A framework for interrogating inclusive practice. European Journal of Special Needs Education, 28(2), 119-135. https://doi.org/10.1080/08856257.2013.778111

Fullan, M. og Hargreaves, A. (2016). Bringing the profession back in: Call to action. https://learningforward. org/wp-content/uploads/2017/08/bringing-the-profession-back-in.pdf 
Gerður G. Óskarsdóttir (ritstjóri). (2014). Starfshattir í grunnskólum við upphaf 21. aldar. Háskólaútgáfan.

Gretar L. Marinósson og Dóra S. Bjarnason. (2016). Próun skóla margbreytileikans í kjölfar Salamanca-yfirlýsingarinnar. Í Dóra S. Bjarnason, Hermína Gunnpórsdóttir og Ólafur Páll Jónsson (ritstjórar), Skóli margbreytileikans: Menntun og manngildi i kjölfar Salamanca (bls. 11-39). Háskólaútgáfan og Rannsóknastofa um skóla án aðgreiningar.

Gretar L. Marinósson og Kristín P. Magnúsdóttir. (2016). Greiningarheiti grunnskólanema: Til íhugunar. Í Dóra S. Bjarnason, Hermína Gunnpórsdóttir og Ólafur Páll Jónsson (ritstjórar), Skóli margbreytileikans: Menntun og manngildi i kjölfar Salamanca (bls. 137-156). Háskólaútgáfan og Rannsóknastofa um skóla án aðgreiningar.

Guðríður Arnardóttir. (2017). Alvarleg tíðindi fyrir samfélagið. Vísir. https://www.visir.is/g/2017170528903

Gutkin, T. B. og Curtis, M. J. (2009). School-based consultation: The science and practice of indirect service delivery. Í T. B. Gutkin og C. R. Reynolds (ritstjórar), The handbook of school psychology (4. útgáfa, bls. 591-635). Wiley.

Hafdís Guðjónsdóttir og Edda Óskarsdóttir. (2020). 'Dealing with diversity’: Debating the focus of teacher education for inclusion. European Journal of Teacher Education, 43(1), 95-109. https://doi.org/10.1080/0 2619768.2019.1695774

Hagstofa Íslands. (e.d.). Starfsfólk í grunnskólum eftir hlutverkum 1998-2019. http://px.hagstofa.is/pxis/ pxweb/is/Samfelag/Samfelag_skolamal_2_grunnskolastig_1_gsStarfsfolk/SKO02307.px/?rxid=5ef2fb1dc193-4b67-adea-6da0704487c8

Hargreaves, A. og Fullan, M. (2012). Professional capital: Transforming teaching in every school. Teacher College Press.

Haug, P. (2017). Understanding inclusive education: Ideals and reality. Scandinavian Journal of Disability Research, 19(3), 206-217. https://doi.org/10.1080/15017419.2016.1224778

Helgi Gíslason og Anna Kristín Sigurðardóttir. (2016). Stefnur sveitarfélaga um skóla án aðgreiningar. Í Dóra S. Bjarnason, Hermína Gunnpórsdóttir og Ólafur Páll Jónsson (ritstjórar), Skóli margbreytileikans: Menntun og manngildi i kjölfar Salamanca (bls. 41-65). Háskólaútgáfan og Rannsóknastofa um skóla án aðgreiningar.

Hermína Gunnpórsdóttir og Ingólfur Ásgeir Jóhannesson. (2014). Additional workload or a part of the job? Icelandic teachers' discourse on inclusive education. International Journal of Inclusive Education, 18(6), 580-600. https://doi.org/10.1080/13603116.2013.802027

Kristín Dýrförð. (2017). . ał sem veldur álagi i leikskólum. https://www.laupur.is/hvad-veldur-alagi-i-leikskolum

Kristín Jónsdóttir og Amalía Björnsdóttir. (2014). Foreldrasamstarf. Í Gerður G. Óskarsdóttir (ritstjóri), Starfshattir i grunnskólum við upphaf 21. aldar (bls. 197-216). Háskólaútgáfan.

Lög um framhaldsskóla nr. 92/2008.

Lög um grunnskóla nr. 91/2008.

Lög um leikskóla, nr. 90/2008.

Manitoba Education and Advanced Learning. (2014). Supporting inclusive schools: A handbook for resource teachers in Manitoba schools. https://www.edu.gov.mb.ca/k12/specedu/res_teacher/pdf/sis_resource_teachers_mb_schools.pdf

Menntamálastofnun. (2018). Grðastarf i grunnskólum: Viðmið og framkvamd ytra mats grunnskóla (2. útgáfa). https://mms.is/sites/mms.is/files/gaedastarf_4.9.2018.pdf

Mennta- og menningarmálaráðuneytið. (2013). Aðalnámskrá grunnskóla: Almennur hluti 2011: Greinasvið 2013.

Mennta- og menningarmálaráðuneytið. (2020). Menntun fyrir alla - horft fram á veginn: Skýrsla unnin fyrir mennta- og menningarmálaráduneyti. https://www.stjornarradid.is/library/01--Frettatengt---myndir-og-skrar/ MRN/MFA_horft\%20fram\%20a\%20veginn_starfshops_vefur.pdf

Mincu, M. E. (2015). Teacher quality and school improvement: What is the role of research? Oxford Review of Education, 41(2), 253-269.

Oliver, M. (2013). The social model of disability: Thirty years on. Disability \& Society, 28(7), 1024-1026. https://doi.org/10.1080/09687599.2013.818773 
Ólafur Páll Jónsson. (2016). Democratic and inclusive education in Iceland: Transgression and the medical gaze. Nordic Journal of Social Research, 7, 77-92. https://doi.org/10.7577/njsr.2097

Pijl, S. J. og Frissen, P. H. (2009). What policymakers can do to make education inclusive. Educational Management Administration \& Leadership, 37(3), 366-377. https://doi.org/ 10.1177/1741143209102789

Rannveig Klara Matthíasdóttir, Amalía Björnsdóttir og Dóra S. Bjarnason. (2013). Skóli án aðgreiningar: Viðhorf sérkennara í grunnskólum til stefnunnar skóli án aðgreiningar. Glaður, 23, 58-68.

Reglugerð um skólapjónustu sveitarfélaga við leik- og grunnskóla og nemendaverndarráð í grunnskólum nr. 444/2019.

Rósa Eggertsdóttir, Gretar L. Marinósson, Carles Sigalés, Ingibjörg Auðunsdóttir, Halldóra Haraldsdóttir, José Pacheco, Marianne Wilhelm og Póra Björk Jónsdóttir. (2002). Batt skilyrði til náms: Starfspróun i heiltaku skólastarfi. Rannsóknarstofnun Kennaraháskóla Íslands.

Samstarfsnefnd Sambands íslenskra sveitarfélaga og Félags grunnskólakennara. (2017). Samantekt samstarfsnefndar Sambands islenskra sveitarfélaga og Félags grunnskólakennara á niðurstöðum i lokaskýrslum sveitarfélaga og umbótaáatlunum grunnskóla vegna úrvinnslubókunar 1 með kjarasamningi aðila. https://www.samband. is/media/kjaramal/FG-lokaskyrsla-samstarfsnefndar-2017_LOK.pdf

Sigrún Daníelsdóttir. (2017). Vellíðan í vinnunni - skólinn sem vinnustaður. https://www.landlaeknir.is/um-embaettid/frettir/frett/item32931/vellidan-i-vinnunni-skolinn-sem-vinnustadur

Sigrún Harðardóttir og Sigrún Júlíusdóttir. (2019). Opinber stefna, skólakerfið og hlutverk kennara: Viðbragðsbúnaður skólans. Stjórnmál og stjórnsýsla, 15(1), 113-134. DOI: 10.13177/irpa.a.2019.15.1.6

Sigurður Arnar Sigurðsson. (2013). Enginn fer neitt á pví sem hann getur ekki en langt á pvi sem hann getur: Sýn foreldra á sérkennslu [meistararitgerð, Háskóli Íslands]. Skemman.is. http://hdl.handle.net/1946/16056

Skoglund, P. (2014). Fundamental challenges and dimensions of inclusion in Sweden and Europe: How does inclusion benefit all? La Nouvelle Revue de l'Adaptation et de la Scolarisation, 65(1), 311-325. DOI: 10.3917/ nras.065.0207

Steingerður Ólafsdóttir, Sigrún Sif Jóelsdóttir, Lára Rún Sigurvinsdóttir, Dóra S. Bjarnason, Anna Kristín Sigurðardóttir og Kristín Erla Harðardóttir. (2014). Skóli án aðgreiningar: Samantekt á lögum og freðilegu efni. https://www.stjornarradid.is/media/menntamalaraduneyti-media/media/ritogskyrslur/skyrsl_skoli_adgr_samant_1\%C3\%B6g_fr_2015.pdf

Watkins, A. og Donnelly, V. (2014). Core values as the basis for teacher education for inclusion. Global Education Review, 1(1), 76-92.

Zubiri-Esnaola, H., Vidu, A., Rios-Gonzalez, O. og Morla-Folch, T. (2020). Inclusivity, participation and collaboration: Learning in interactive groups. Educational Research, 62(2), 162-180. https://doi.org/10.10 80/00131881.2020.1755605

Póra Björk Jónsdóttir. (2018). Ytra mat á grunnskólastarfi 2013 til hausts 2018: Niðurstöður mats með notkun fyrstu útgáfu Gœðastarfs i grunnskólum. https://mms.is/sites/mhttps://mms.is/sites/mms.is/files/samantekt_ og_arsskyrsla_haust_2018.pdf

Edda Óskarsdóttir, Hermína Gunnpórsdóttir, Birna M. Svanbjörnsdóttir og Rúnar Sigpórsson. (2021).

Framkvæmd stefnu um menntun fyrir alla á Íslandi: Viðhorf skólafólks og tillögur um aðgerðir

Netla - Veftímarit um uppeldi og menntun. Menntavísindasvið Háskóla Íslands.

Sótt af https://netla.hi.is/greinar/2021/alm/07.pdf

DOI: https://doi.org/10.24270/netla.2021.7 